\title{
Development of a Low-Molecular-Weight A $\beta 42$ Detection System Using a Enzyme-Linked Peptide Assay
}

\author{
Sang-Heon Kim ${ }^{1,+}{ }^{\oplus}$, Eun-Hye Lee ${ }^{2,+}{ }^{+}$Hyung-Ji Kim ${ }^{3,+}{ }^{+}$A-Ru Kim ${ }^{1}$, Ye-Eun Kim ${ }^{2,4}$, Jae-Hong Lee ${ }^{3, *}$, \\ Moon-Young Yoon $1, * \mathbb{D}$ and Seong-Ho Koh $2,4, *$ (i)
}

1 Department of Chemistry and Research, Institute of Natural Sciences, Hanyang University,

Seoul 04763, Korea; konasi2@naver.com (S.-H.K.); kimr2122@gmail.com (A.-R.K.)

2 Departments of Neurology, Hanyang University Guri Hospital, Guri 11923, Korea; gpdmsd1123@hanmail.net (E.-H.L.); yebong0207@daum.net (Y.-E.K.)

3 Department of Neurology, University of Ulsan College of Medicine, Asan Medical Center, Seoul 05505, Korea; garailsikzip@gmail.com

4 Department of Translational Medicine, Hanyang University Graduate School of Biomedical Science \& Engineering, Seoul 04763, Korea

* Correspondence: jhlee@amc.seoul.kr (J.-H.L.); myyoon@hanyang.ac.kr (M.-Y.Y.); ksh213@hanyang.ac.kr (S.-H.K.); Tel.: +82-2-3010-3446 (J.-H.L.); +82-2-2220-0946 (M.-Y.Y.); +82-31-560-2260 (S.-H.K.)

$+\quad$ These authors (S.-H.K., E.-H.L., and H.-J.K.) equally contributed to this work.

Citation: Kim, S.-H.; Lee, E.-H.; Kim, H.-J.; Kim, A.-R.; Kim, Y.-E.; Lee, J.-H.; Yoon, M.-Y.; Koh, S.-H. Development of a Low-Molecular-Weight A $\beta 42$ Detection System Using a Enzyme-Linked Peptide Assay. Biomolecules 2021, 11, 1818. https://doi.org/10.3390/ biom 11121818

Academic Editor: Marcus O. W. Grimm

Received: 25 October 2021

Accepted: 1 December 2021

Published: 2 December 2021

Publisher's Note: MDPI stays neutral with regard to jurisdictional claims in published maps and institutional affiliations.

Copyright: (c) 2021 by the authors. Licensee MDPI, Basel, Switzerland. This article is an open access article distributed under the terms and conditions of the Creative Commons Attribution (CC BY) license (https:/ / creativecommons.org/licenses/by/ $4.0 /)$.

\begin{abstract}
Alzheimer's disease (AD) is a degenerative brain disease that is the most common cause of dementia. The incidence of $\mathrm{AD}$ is rapidly rising because of the aging of the world population. Because AD is presently incurable, early diagnosis is very important. The disease is characterized by pathological changes such as deposition of senile plaques and decreased concentration of the amyloid-beta 42 (A $\beta 42$ ) peptide in the cerebrospinal fluid (CSF). The concentration of A $\beta 42$ in the CSF is a well-studied AD biomarker. The specific peptide probe was screened through four rounds of biopanning, which included the phage display process. The screened peptide showed strong binding affinity in the micromolar range, and the enzyme-linked peptide assay was optimized using the peptide we developed. This diagnostic method showed specificity toward A $\beta 42$ in the presence of other proteins. The peptide-binding site was also estimated using molecular docking analysis. Finally, the diagnostic method we developed could significantly distinguish patients who were classified based on amyloid PET images.
\end{abstract}

Keywords: Alzheimer's disease; amyloid-beta 42; phage display; peptide-based assay

\section{Introduction}

Alzheimer's disease (AD) is a neurodegenerative disease that causes the most common form of dementia. It leads to memory loss, cognitive and physical impairment, and finally death [1,2]. The incidence of AD is continuously increasing in the United States and the Republic of Korea [3-5]. Although many studies have investigated the treatment of AD, it is still deemed an incurable disease. By the time the symptoms of AD manifest, pathological processes-such as amyloid and tau deposition and related neurodegeneration-have already occurred in the brain. Currently available AD drugs address only the symptoms of dementia, not the underlying AD pathologies. Aducanumab (Aduhelm) was approved by the U.S. Food and Drug Administration in June 2021, and several disease-modifying therapies targeting $\beta$-amyloid have been studied; however, there is a long way to go to cure AD [6], leaving early diagnosis as the key to effective treatment $[7,8]$.

There are many well-researched biomarkers of common neurodegenerative diseases such as amyloid protein, tau protein, and $\alpha$-synuclein [9]. The amyloid-beta 42 (A $\beta 42)$ peptide is a one of the well-known biomarkers for the diagnosis of AD. It is produced through proteolytic cleavage of the amyloid precursor protein $[10,11]$. Although the 
mechanism of action is unclear, the overproduction of $A \beta 42$ has been widely researched in AD diagnosis [12,13]. Abnormally accumulated $A \beta 42$ is prone to aggregating into senile plaques, which are one of the main pathological hallmarks of AD [14,15]. Due to the accumulation of large molecular aggregates in the brain, the concentration of smaller A $\beta 42$ oligomers, which can pass through the brain-cerebrospinal fluid (CSF) barrier, decreases. Reduced A $\beta 42$ concentration in the CSF can be a sign of AD [16-20].

$A \beta 42$ has been detected in numerous experiments, and most of them have used antibodies to detect $A \beta 42$ directly [21-23]. Antibodies are the most representative biological molecules used for target probing, and antibody engineering has been also researched even in AD [24]. Because of their high specificity and binding affinity, they have been used in many diagnostic assays [25]. The enzyme-linked immunosorbent assay (ELISA) is the most commonly used diagnostic assay for detecting target molecules using antibodies. ELISA has some advantages, such as having a simple procedure and high specificity and sensitivity. Moreover, it is generally safe and eco-friendly. ELISA also has some disadvantages, such as instability caused by using antibodies, expensive culture media, and the labor and cost involved in antibody preparation [26]. Moreover, the use of antibodies to detect A $\beta 42$ has an obvious disadvantage: because $\mathrm{A} \beta 42$ is a very small protein $(4 \mathrm{kDa})$ and antibodies, produced to react with $A \beta 42$ monomers, have much larger sizes, the c-terminus of $A \beta 42$ in oligomeric structures can be hidden for reaction in a sandwich ELISA system [27,28].

To overcome the limitations of using an antibody as a diagnostic probe, a small peptide probe was investigated. Peptide probes have been suggested as alternatives to antibodies in many studies [29-32]. Small peptide probes can bind to specific targets because of the non-covalent bonds established between peptides and targets, such as hydrogen bonds, ionic bonds, and van der Waals forces. Furthermore, the use of peptide aptamers for the detection of $\mathrm{A} \beta 42$ has some advantages, especially for detecting low-molecular-weight $\mathrm{A} \beta 42$ oligomers, owing to their small size. Compared to an antibody, a peptide probe has better accessibility and is far less influenced by steric hindrance when it binds to the target [33-36].

Phage display is the most frequently used biopanning method for screening peptide probes. M13 bacteriophages displaying different peptide sequences on their capsids, according to their genotypes, were used [37]. Phage libraries have $10^{10}$ random sequences, and these libraries are sorted through high-throughput screening to identify the most specific phage for the target. The "stickier" phages-those that bind more strongly to the target-occupy the phage pools via affinity selection, while the non-binding phages are removed through consecutive biopanning rounds. Phage display is a useful technique for researching protein-protein interactions, drug discovery, and estimating the epitope of the antigen. It is especially helpful for finding new ligands, such as enzyme inhibitors, receptor agonists, antagonists, and probes that have a targeting moiety [38,39].

In this study, we mimicked an ELISA system for A $\beta 42$ detection using a small peptide probe to avoid the disadvantages associated with using an antibody as a diagnostic probe in a sandwich ELISA. We screened novel peptide probes using phage display. The concentrations of $\mathrm{A} \beta 42$ in the CSF were estimated and cross-checked with the brain amyloid status based on positron emission tomography (PET) imaging.

\section{Materials and Methods}

\subsection{Materials}

$\mathrm{A} \beta 42$ (ab120301), A $\beta 40$ (ab120479), and anti- $\beta$ amyloid antibody (ab2539) were purchased from Abcam (Cambridge, UK). 1,1,1,3,3,3-Hexafluoro-2-propanol was purchased from Sigma-Aldrich (St. Louis, MO, USA). Protein G-coated plates were purchased from Thermo Fisher Scientific (Waltham, MA, USA). Anti- $\beta$-amyloid 1-42 (AB5078P) and anti- $\beta$-amyloid 1-40 (AB5074P) antibodies were purchased from Merck (Kenilworth, NJ, USA). M13 phages were purchased from New England Biolabs (Ipswich, MA, USA). The studied A $\beta 42$-binding peptide probe (ABPP) sequences were synthesized by AnyGen (Gwangju, Korea). Streptavidin-HRP was obtained from BD Difco Laboratories (Sparks, NV, USA). 3,3',5,5'-tetramethylbenzidine (TMB) solution was purchased from R\&D Sys- 
tems (Minneapolis, MN, USA). All chemicals were obtained from commercial sources and were of the highest quality available.

\subsection{Optimization of the Binding Conditions for Phage Display}

We added $100 \mu \mathrm{L}$ of an anti- $\beta$-amyloid $1-42$ solution $(0,0.5,1,2,4,6,8$, or $10 \mu \mathrm{g} / \mathrm{mL})$ and fluorescein isothiocyanate (FITC)-conjugated antibody $(2 \mu \mathrm{g} / \mathrm{mL})$ in phosphate-buffered saline (PBS; pH 7.4) to the protein G-coated opaque plates and incubated these for $2 \mathrm{~h}$. Wells were washed three times with PBST (PBS with 0.05\% Tween 20) after discarding the unbound reactants. The fluorescence intensity (excitation wavelength, $495 \mathrm{~nm}$; emission wavelength, $520 \mathrm{~nm}$ ) was estimated after three washes. Then, $100 \mu \mathrm{L}$ of anti- $\beta$-amyloid 1-42 $(8 \mu \mathrm{g} / \mathrm{mL})$ in PBS was added to each well and incubated for $2 \mathrm{~h}$. After antibody fixation, an excessive concentration of $\mathrm{A} \beta 42(200 \mathrm{ng} / \mathrm{mL})$ was added to each antibody-coated plate for $2 \mathrm{~h}$. Monomerized amyloid solutions were prepared as previously described [40]. The optimized plates were used for the next screening step.

\subsection{In Vitro Phage Screening against Amyloid-Beta 42}

A random phage library of $10^{10}$ random sequences was used for the first round of screening. Each round of biopanning was performed under different conditions (Table 1). Protein G-coated plates were coated with A $\beta 42$ after antibody fixation. Phages at a constant concentration were added to the A $\beta 42$-coated wells, and the non-bound phages were washed out using Tris-buffered saline (TBS) with $0.05 \%$ Tween 20 . The elution buffer containing $0.2 \mathrm{M}$ glycine- $\mathrm{HCl}$ and $1 \mathrm{mg} / \mathrm{mL}$ bovine serum albumin (BSA; $\mathrm{pH} 2.2$ ) was administered to elute the bound phages, and the eluate was neutralized using $1 \mathrm{M}$ Tris- $\mathrm{HCl}$ ( $\mathrm{pH}$ 9.1; Figure 1A). Negative selection was performed to reduce the quantity of nonspecific phages, by adding the amplified phages to a plate coated only with the antibody for $1 \mathrm{~h}$. Non-bound phages in the supernatant were used for positive selection. The eluted phages were titrated by testing for plaque forming units. For this test, the base of a sterile Petri dish was covered with LB top agar, followed by a mixture of E. coli and a dilution of the bacteriophage sample. Growth of E.coli would form a lawn of cells in the top agar layer, whereas phage replication would result in the formation of clear zones or 'plaques' [41].

Table 1. Conditions of phage display.

\begin{tabular}{cccc}
\hline Round \# & Binding Condition & Binding Time (min) & Washing Conditions \\
\hline 1R & TBS & 120 & $0.1 \%$ TBST \\
2R & TBS & 60 & $0.1 \%$ TBST \\
3R & TBS & 60 & $0.1 \% \mathrm{TBST}$ \\
Negative & TBS + 0.5\% BSA & 60 & \\
4R & TBS + 0.5\% BSA & 30 & $0.1 \%$ TBST, $500 \mathrm{mM} \mathrm{NaCl}$ \\
\hline
\end{tabular}

(A)

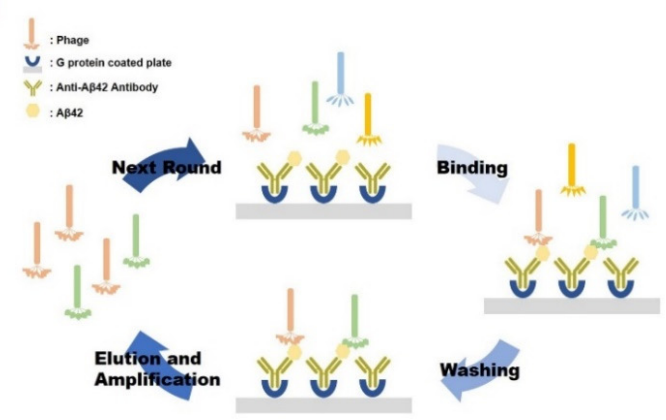

(B)

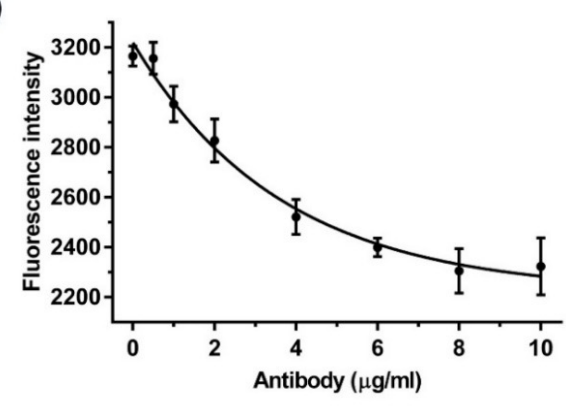

Figure 1. Scheme of biopanning and optimization of the screening conditions. (A) Most specific phages were screened via binding, washing, elution, and amplification steps, a procedure called biopanning. (B) The fluorescence signal from the FITC-labeled antibodies decreased as the concentration of anti-A $\beta 42$ antibodies increased. The test was performed in triplicate under the same conditions. 


\subsection{Analysis of the Screened Phages}

After four rounds of biopanning, each screened phage presenting its own peptide sequence was analyzed. Sixty phage plaque forming units resulting from biopanning were randomly selected, and the chosen phages were infected with Escherichia coli strain ER 2738. Afterwards, plasmid DNA coding for the peptide sequences was extracted via ethanolic precipitation. The extracted DNA was sequenced using the following primer: 5'-CCCTCATAGTTAGCGTAACG-3' (100 pmol, New England Biolabs). Each analyzed phage was amplified by infection with the ER 2738 strain [42].

\subsection{Characterization of the Binding Properties of Synthetic Peptides}

The studied A $\beta$-binding peptide probe (ABPP) sequences (S E P Q N I W Q Y L R N) were synthesized by AnyGen (Gwangju, Korea). ABPP was conjugated with biotin as a signal reporter, with a purity greater than $95 \%$, as assessed using high-performance liquid chromatography. The binding affinities of peptides were estimated for each A $\beta 42$ - and antibody-coated plate. The coating methods followed the protocol described above, except for the use of PBST instead of TBST. After coating the plate with A $\beta 42$, serially diluted peptide was added to the plate for $1 \mathrm{~h}$. After peptide incubation, all wells were washed four times with PBST. Next, the wells were incubated with $100 \mu \mathrm{L}$ of streptavidin-HRP (1:4000 in PBST) for $1 \mathrm{~h}$. After incubation, the solution in the wells was washed four times with PBST. TMB solution was added to each well for $15 \mathrm{~min}$. Next, $100 \mu \mathrm{L}$ of $1 \mathrm{M}$ $\mathrm{H}_{2} \mathrm{SO}_{4}$ was added to the wells to stop the reaction, and the absorbance was measured at $450 \mathrm{~nm}$ (OD450) using a microplate reader. To determine the detection range, serially diluted $A \beta 42$ was added to the antibody-coated plates. After washing, the plate was incubated for $1 \mathrm{~h}$ with $100 \mu \mathrm{L}$ of $100 \mu \mathrm{M}$ peptide. Streptavidin and TMB treatment steps were performed as described above. Based on the measurements, the limit of detection (LOD) for the diagnostic system was calculated according to the formula from the IUPAC: $\mathrm{LOD}=3 \times S D /$ slope. To verify the specificity of our diagnostic system, other amyloid proteins were added to the antibody-coated plates. Then, $100 \mu \mathrm{L}$ of $100 \mu \mathrm{M}$ of peptide was added to each protein-treated plate and incubated for $1 \mathrm{~h}$. Streptavidin and TMB treatment steps were performed as described above.

\subsection{Estimation of the Binding Site of the Developed Peptides}

Anti-A $\beta 42$ and anti-A $\beta 40$ antibodies were applied to the protein G-coated plates and incubated for $2 \mathrm{~h}$. After washing, $A \beta 42$ and $A \beta 40$ were used to consecutively treat each antibody-coated plate for $2 \mathrm{~h}$. Next, $100 \mu \mathrm{L}$ of $100 \mu \mathrm{M}$ peptide was added to each protein-treated plate, which was then incubated for $1 \mathrm{~h}$. Streptavidin and TMB treatment steps and absorbance measurements were performed as described above. In addition, two kinds of antibodies - which recognize different epitopes (anti-A $\beta 40$; C-terminus of $A \beta 40$ and anti-amyloid $\beta$ protein; $1-14$ sequence of $A \beta 40$ ) - were added to the protein G-coated plates and incubated for $2 \mathrm{~h}$. The coated plates were washed thrice with PBST. After antibody coating, the same concentration of $A \beta 40$ was administered to the plates, followed by incubation for $2 \mathrm{~h}$. The plates were cleaned three times with PBST. Then, $100 \mu \mathrm{L}$ of $100 \mu \mathrm{M}$ peptide was added to each protein-treated plate and incubated for $1 \mathrm{~h}$. Streptavidin and TMB treatment steps were performed as described above.

\subsection{Molecular Docking of $A \beta 42$ and Peptide}

Molecular docking analysis of the peptide against $\mathrm{A} \beta 42$ was performed using AutoDock Vina [43]. The binding site of the peptide to $A \beta 42$ was also estimated. Accordingly, for the A $\beta 42$ crystal structure, we selected the receptor protein 1Z0Q [44]. To calculate a more realistic ligand-protein interaction, the flexible and non-flexible residues were identified and appropriate charges were added. The peptide ligand was modeled with free torsional bonds in its structure. The docking area was calculated using a three-dimensional grid box with grid points of $62 \times 60 \times 62 \AA$ and a line spacing of $0.375 \AA$. 


\subsection{Recovery Test of $A \beta 42$ at Different Spiking Levels}

PBS and human serum were used as solutions for the spiking test. Each of the A $\beta 42$ and $\mathrm{A} \beta 40$ stock solutions was diluted using PBS, and the mixture was diluted using human serum. The diluted samples were added to antibody-coated plates and incubated for $2 \mathrm{~h}$. The binding conditions used for the antibody coating and the peptide, streptavidin, and TMB treatment steps are described above. To calculate the recovery ratio, we divided the signals of the mixtures by the signals of $A \beta 42$.

\subsection{Participants}

This study consecutively and prospectively enrolled 98 participants who visited the memory clinic of Asan Medical Center, Seoul, South Korea, from June 2018 to July 2020. All participants or their proxies provided informed consent. All participants underwent brain MRI, detailed neuropsychological testing, fluorine-18 $\left({ }^{18} \mathrm{~F}\right)$-florbetaben amyloid PET, and CSF analysis. The participants who were included in the study met the following criteria: they (1) were aged over 40 and under 90 years; (2) showed cognitive impairment, which included subjective cognitive decline (SCD), mild cognitive impairment (MCI), and dementia, and was defined by subject memory impairment reported by the patients or caregivers, activities of daily living, as judged by a physician, and objective memory decline below the 16th percentile ( -1 standard deviation) for the demographically matched norms determined via neuropsychological testing; and (3) showed no evidence of structural lesion on a brain MRI that could influence cognitive function. All PET images were obtained using Discovery 690, 710, and 690 Elite PET/computed tomography scanners (GE Healthcare, Chicago, IL, USA). Amyloid PET images were acquired for $20 \mathrm{~min}$, beginning $90 \mathrm{~min}$ after injection of $300 \pm 30 \mathrm{MBq}$ of ${ }^{18}$ F-florbetaben. Two neurologists (H.J.K. and J.H.L) and two nuclear medicine physicians reviewed the PET scans according to the predefined regional cortical tracer binding and brain amyloid plaque load (BAPL) scoring system [45]. The final score was reached by consensus, with a BAPL score of 1 regarded as A $\beta-$, and BAPL scores of 2 and 3 considered $A \beta+[46,47]$. All participants underwent blood tests, in which a complete blood count, lipid profiles, erythrocyte sedimentation rate (ESR), vitamin B12, folate, homocysteine serum levels, and thyroid function were assessed. The ApoE genotype was identified after extracting genomic DNA from the venous blood.

\subsection{Neuropsychological Assessment}

When referring to a pathological change in the AD continuum, it is necessary to consider the clinical status of the patient. All patients were assessed using the Seoul Neuropsychological Screening Battery (SNSB) as a formal test to accurately describe their cognitive status as SCD, MCI, or dementia [48]. The SNSB is a detailed neuropsychological battery that includes various tests that measure attention (forward/backward digit span), language (comprehension, repetition, confrontational naming, reading, and writing), calculation, praxis (buccofacial and ideomotor), visuospatial function (Rey Complex Figure Test; RCFT), verbal memory (Seoul Verbal Learning Test with immediate recall, delayed recall, and recognition), visual memory (RCFT with immediate recall, delayed recall, and recognition), and frontal/executive functions (contrasting program, go/no-go test, verbal fluency, and the Stroop test). We also performed other clinical and cognitive performance measurements, including the Korean version of the Mini-Mental State Examination (K-MMSE), Global Deterioration Scale (GDS), Clinical Dementia Rating (CDR), Korean version of the Neuropsychiatric Inventory, and the 30-item Geriatric Depression Scale (GDS-30).

\subsection{ELISA}

The concentration of A $\beta 42$ in the CSF was examined using a commercial ELISA kit (R\&D Systems, Minneapolis, USA) according to the manufacturer's instructions. Briefly, the CSF samples were added to human A $\beta 42$ monoclonal antibody-coated microplates and incubated for $2 \mathrm{~h}$ at $2-8{ }^{\circ} \mathrm{C}$. The unbound substances were washed away, and the molecules presenting only $A \beta 42$ were attached to the capture antibody. Then, the captured $A \beta 42$ was 
detected using enzyme-linked monoclonal antibodies for another $2 \mathrm{~h}$ at $2-8^{\circ} \mathrm{C}$. Substrates were added to the microplates, and color development was measured using a microplate reader at a wavelength of $450 \mathrm{~nm}$.

\subsection{Verification of the Diagnostic Ability of the Peptide-Based Detection System}

CSF samples from patients were added to antibody-coated plates and incubated for $2 \mathrm{~h}$. The binding conditions used for antibody coating and the peptide, streptavidin, and TMB treatment steps are described above.

\subsection{Statistical Analysis}

GraphPad Prism 6 was used for statistical analysis. Statistical analyses of the demographics of the participants were conducted as follows. Student's $t$-test was used to analyze the age, educational level, disease duration, MMSE, CDR, neutrophil, monocyte, ESR, C-reactive proteins (CRP), and low-density lipoprotein (LDL) levels. The $\chi^{2}$ test was used to analyze the sex distribution, apolipoprotein $\mathrm{E}(A p o E) \varepsilon 4$ allele, diabetes mellitus (DM), hypertension (HTN), and hyperlipidemia. For the ELISA and ABPP sensitivity and specificity tests, Student's $t$-tests and ROC analyses were used.

\section{Results}

\subsection{Optimization of the Binding Conditions of the Diagnostic System}

As the concentration of anti-A $\beta 42$ antibody increased, the fluorescence intensity of the FITC-labeled antibody decreased. Due to occupation by a non-labeled anti-A $\beta 42$ antibody, FITC-labeled antibody could not bind to the plate. Saturation of the anti-A $\beta 42$ antibody was observed at $8 \mu \mathrm{g} / \mathrm{mL}$ (Figure 1B).

\subsection{Characterization of the Peptide Using the Diagnostic System}

The screened peptide sequences are presented in Table 2. Only two different sequences were found at a higher frequency than the other sequences. One peptide sequence (S E P Q N I W Q Y L R N) was chosen for the synthesis. The binding affinities of the screened peptides were calculated. Serially diluted peptides showed saturation according to Hillslope fitting. The binding affinity of the peptide is shown in Figure 2. The absorbance increased with increasing peptide concentration and reached saturation near a peptide concentration of $100 \mu \mathrm{M}$. The dissociation constant $\left(\mathrm{K}_{\mathrm{D}}\right)$ for the ABPP was $17.47 \pm 2.98 \mu \mathrm{M}$ (Figure 2A). The detection range of the diagnostic system using our screened peptides was also estimated using serially diluted $A \beta 42$. It showed good linear calibration between the concentration of $A \beta 42$ and absorbance in the range $1.25-80 \mathrm{ng} / \mathrm{mL}$ (Figure 2B). In addition, we verified the ability of our diagnostic methods to distinguish between $A \beta 42$ and other proteins in solution. Significantly higher signals were obtained for A $\beta 42$ than for the other proteins (Figure 2C).

Table 2. Analyzed peptide sequences.

\begin{tabular}{ccc}
\hline Phage \# & Sequence & Frequency (30/60) \\
\hline 9 & SE P Q N I W Q Y L R N & 20 \\
21 & I W M T R T N L N D V N & 10 \\
\hline
\end{tabular}


(A)

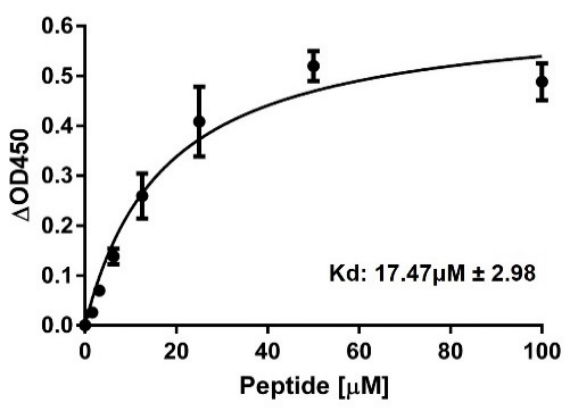

(B)

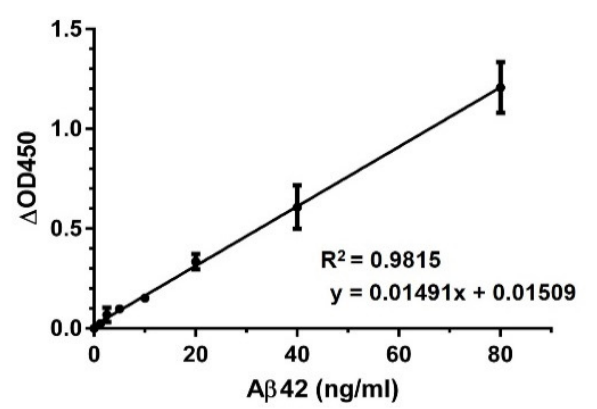

(C)

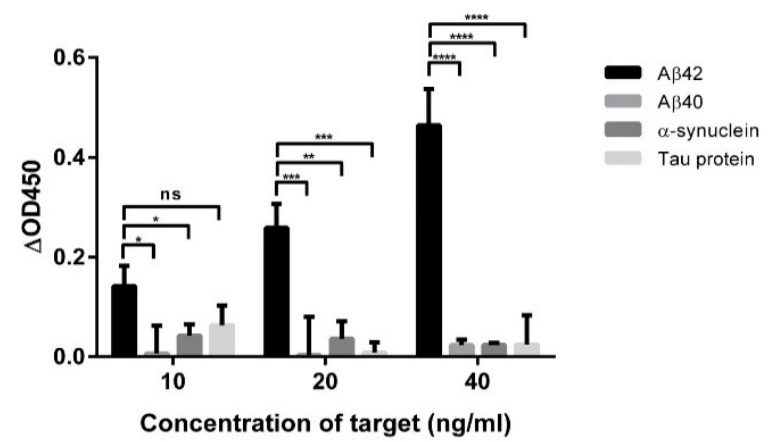

Figure 2. Characterization of binding of the screened peptide. (A) The peptide showed strong binding affinity in the micromolar range with a $\mathrm{K}_{\mathrm{D}}$ of $17.47 \pm 2.98 \mu \mathrm{M}$. (B) Linear regression of binding between A $\beta 42$ and $\mathrm{ABPP}\left(R^{2}=0.9815\right)$. (C) Specificity test on an anti-A $\beta 42$ antibody-coated plate. Only A $\beta 42$ showed meaningful signals. One-way ANOVA analysis was performed for statistical analysis (ns $p>0.05,{ }^{*} p \leq 0.05,{ }^{* *} p \leq 0.01,{ }^{* * *} p \leq 0.001,{ }^{* * * *} p \leq 0.0001$ ). All tests were performed in triplicate under the same conditions.

\subsection{Estimation of the Epitope Recognized by the Screened Peptide}

Adding $A \beta 42$ to anti-A $\beta 42$ antibody-coated plates presented a large signal contrast compared to the addition of $A \beta 42$ to anti-A $\beta 40$ antibody (Figure $3 A, B$ ). The signals obtained by adding $A \beta 42$ to an anti-A $\beta 42$ antibody-coated plate were much higher than those obtained by adding $A \beta 40$ to an anti-A $\beta 40$ antibody-coated plate (Figure $3 C, D)$. When $A \beta 40$ was added, we measured much higher absorbance values with an antibody that could recognize the 1-14 sequence of $A \beta 40$ than when we used an antibody that could recognize seven amino acids from the $\mathrm{C}$-terminus of $\mathrm{A} \beta 40$ (Figure $4 \mathrm{~A}$ ). To estimate the peptide-binding site, molecular docking of the screened peptide with $\mathrm{A} \beta 42$ was performed. Docking analysis showed that the peptide was bound to the mid-to-end region of the $A \beta 42$ sequence. In particular, the polypeptide chains of K16 and F20 in A $\beta 42$ formed hydrogen bonds with the peptide chains of R11 and L10 in the screened peptide. In addition, hydrogen bonds between the peptide chains of the 30A, I31, I32, G33, and L34 residues in A 342 and the peptide chains of the S1, E2, and W7 residues in the peptide ligand were formed. The binding energy between $\mathrm{ABPP}$ and $\mathrm{A} \beta 42 \mathrm{was}-4.3 \mathrm{kcal} / \mathrm{mol}$ (Figure $4 \mathrm{~B}$ ).

\subsection{Recovery Test of $A \beta 42$}

Different concentrations of $A \beta 42$ and $A \beta 40$ were spiked into blank PBS and human serum samples. They were analyzed using the methods described above. In all spiked mixtures, the average recoveries of $A \beta 42$ ranged from $96.03 \%$ to $104.51 \%$ and showed a $\%$ RSD of approximately $10 \%$ when using PBS as the solution (Figure 5 and Table 3 ). 
(A)

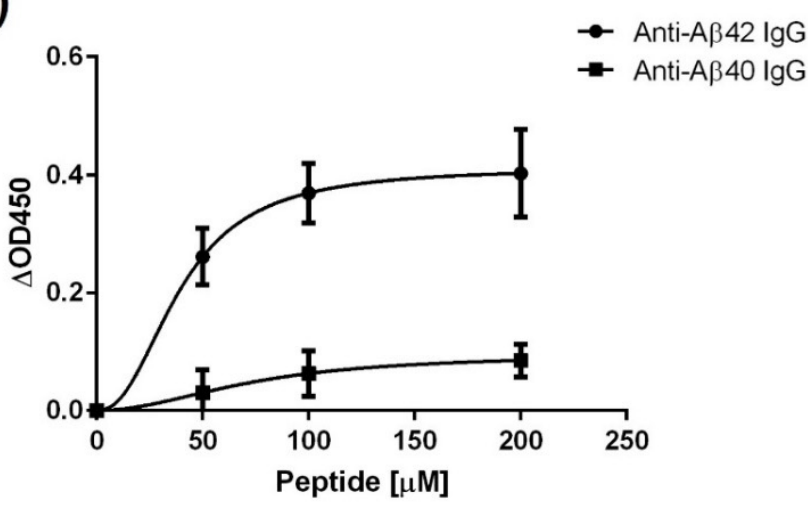

(C)

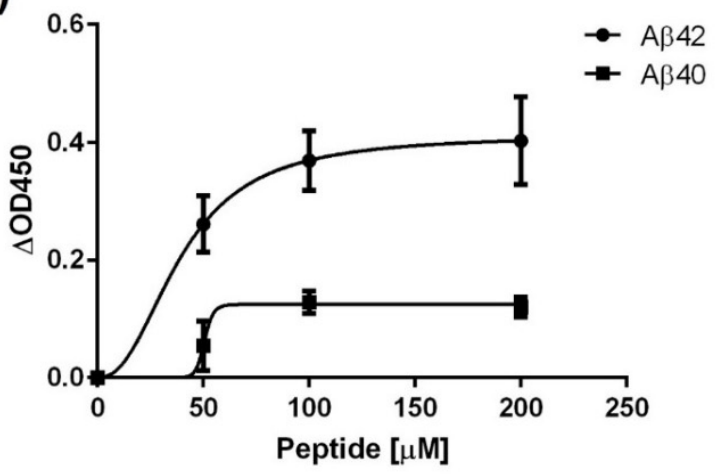

(B)

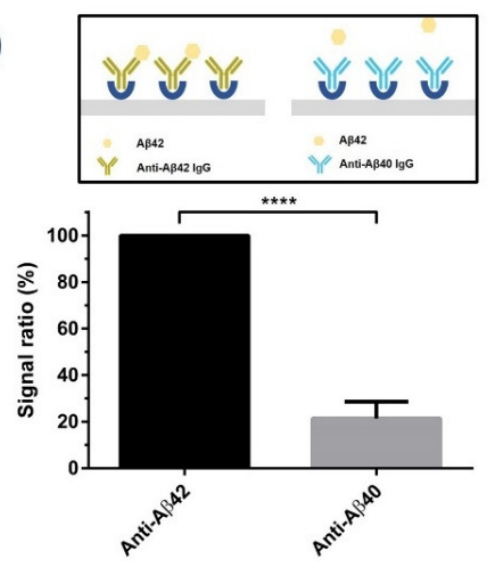

(D)
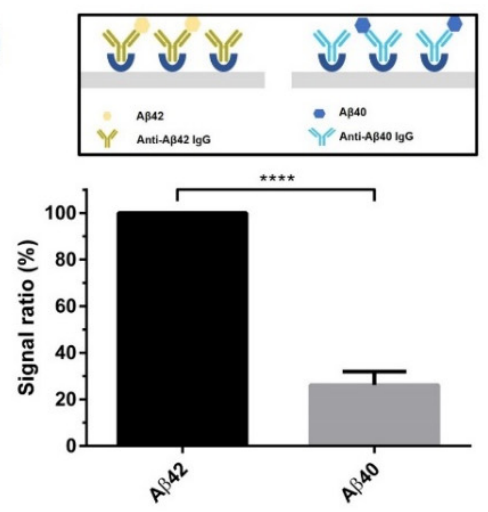

Figure 3. Verification of the A $\beta$-specific binding in the peptide-based diagnostic method. (A) Comparison of signals using two kinds of $A \beta$-specific antibodies. The signal was shown only when using the anti-A $\beta 42$ antibody when $A \beta 42$ was added to the antibody-coated plate. (B) The ratio of signals resulting from using the anti-A $\beta 42$ antibody and the anti-A $\beta 40$ antibody with $A \beta 42$. An unpaired $t$-test was performed for statistical analysis ( $\left.{ }^{* * * *} p \leq 0.0001\right)$. (C) Comparison of signals when $A \beta 42$ and $A \beta 40$ were added to plates coated with antibodies specific to each respective $A \beta$ species. (D) The ratio of signals resulting from $A \beta 42$ detection by anti-A $\beta 42$ antibody to those resulting from $A \beta 40$ detection by anti-A $\beta 40$ antibody on antibody-coated plates specific to each of the A $\beta$ species. An unpaired $t$-test was performed for statistical analysis $(* * * * p \leq 0001)$. All tests were performed in triplicate under the same conditions.

(A)

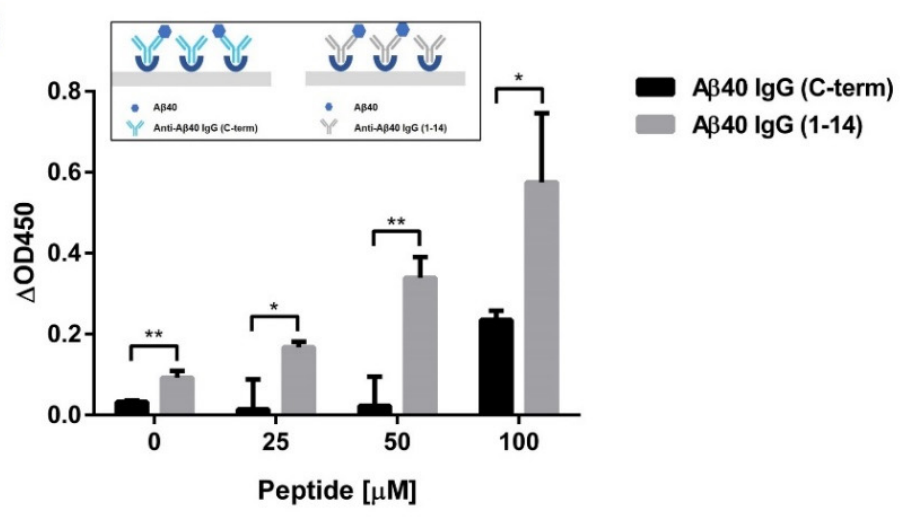

(B)

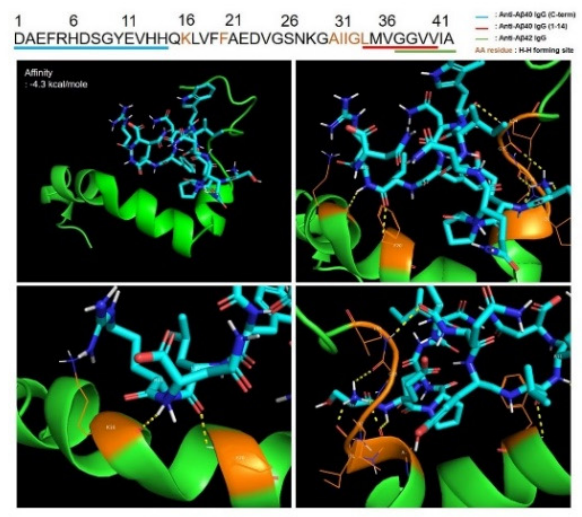

Figure 4. Estimation of the peptide binding sites in A $\beta 42$. (A) Signal difference of $A \beta 40$ between two types of antibodies that recognized different epitopes. Multiple $t$-test was performed for statistical analysis $\left({ }^{*} p \leq 0.05,{ }^{* *} p \leq 0.01\right)$. The test was performed in triplicate under the same conditions. (B) Molecular docking analysis of peptide binding to A $\beta 42$. 


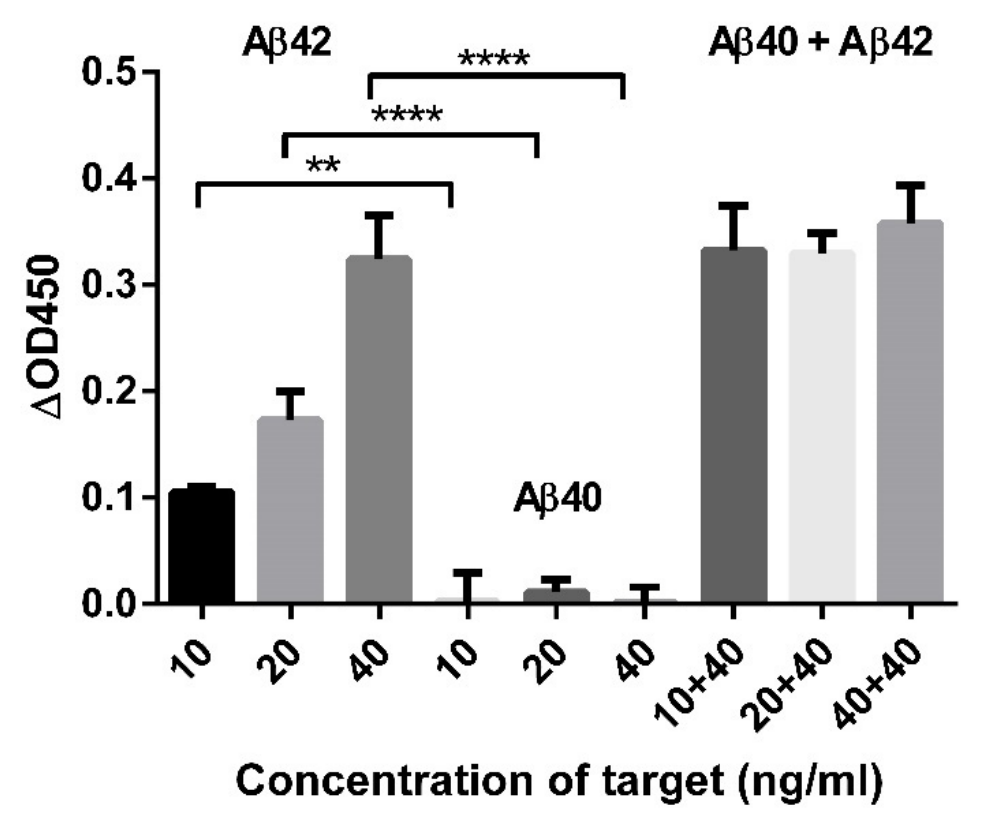

Figure 5. Spiking and recovery in protein mixtures. A specific concentration of A $\beta 42$ was spiked, and the average recovery signals were estimated. One-way ANOVA followed by Dunnett's multiple comparisons tests were performed for statistical analysis $\left.{ }^{* *} p \leq 0.01,{ }^{* * * *} p \leq 0.0001\right)$. All tests were performed in triplicate under the same conditions.

Table 3. Spiking and recovery rate.

\begin{tabular}{cccc}
\hline $\begin{array}{c}\text { Concentration of Target } \\
(\mathbf{A} \boldsymbol{\beta} \mathbf{4 0}+\mathbf{A} \boldsymbol{\beta} \mathbf{4 2}, \mathbf{n g} / \mathbf{m L})\end{array}$ & Average Recovery (\%) & Standard Deviation (\%) & \%RSD \\
\hline $10+40$ & 97.02 & 12.46 & 12.84 \\
$20+40$ & 96.04 & 5.81 & 6.053 \\
$40+40$ & 104.5 & 10.51 & 10.15 \\
\hline
\end{tabular}

\subsection{Characteristics of Participants}

The detailed demographic and clinical characteristics of the participants are presented in Table 4. The members of the $A \beta$ - group were older than those in the $A \beta+$ group. The $\mathrm{A} \beta+$ group included 24 patients with early onset AD. Except for the early onset subjects, there was no difference in age between the two groups. Of note, the frequency of the $A p o E \varepsilon 4$ allele was significantly higher in the $\mathrm{A} \beta+$ group (76.9\%) than in the $\mathrm{A} \beta$ - group $(23.1 \%)$. The frequency of $D M$ was higher in the $A \beta-$ group than in the $A \beta+$ group. Serum ESR was higher in the $A \beta$ - group, and LDL levels were higher in the $A \beta+$ group. Other demographic factors, including sex distribution, disease duration, educational level, frequency of HTN, and hyperlipidemia, were not significantly different between the two groups.

\subsection{Accuracy Validation of the Diagnostic Methods by Cross Checking with the PET Images}

Amyloid PET imaging is one of the main medical approaches used to diagnose AD. The participants were divided into two groups_amyloid-positive and amyloid-negative-based on the existence of deposited amyloid proteins (Figure 6). ELISA and the diagnostic system using ABPP were performed on the CSF samples of the participants, and their specificities and sensitivities regarding $A \beta 42$ detection were compared. The amyloid-positive group showed significantly lower levels of A $\beta 42$ in the CSF than the amyloid-negative group, according to both detection methods (Figure 7A,B). ELISA classified the amyloid PET-positive and -negative participants with $67.3 \%$ sensitivity and $69.6 \%$ specificity, whereas the peptide system had $61.5 \%$ sensitivity and $65.2 \%$ specificity (Figure 7 C,D). 
Table 4. Demographics and characteristics.

\begin{tabular}{|c|c|c|c|}
\hline & & Amyloid-Negative & Amyloid-Positive \\
\hline \multirow{5}{*}{ Population } & Sex, $n$ (female) & $46(21)$ & $52(32)$ \\
\hline & Age (SD), $\mathrm{y}^{*}$ & $71.67(8.57)$ & $66.73(10.36)$ \\
\hline & Education level (SD), y & $11.67(4.68)$ & $11.41(4.77)$ \\
\hline & Disease duration (SD), $\mathrm{m}$ & $28.52(28.89)$ & $35.62(27.10)$ \\
\hline & ApoE $\varepsilon 4$ carrier, $n(\%) * *$ & $9(23.1)$ & $30(76.9)$ \\
\hline \multirow{3}{*}{ Underlying disease } & $\mathrm{DM}, n(\%) *$ & $22(46.9)$ & $10(19.2)$ \\
\hline & HTN, $n(\%)$ & $21(45.7)$ & $25(54.3)$ \\
\hline & Hyperlipidemia, $n(\%)$ & $18(40.9)$ & $26(59.1)$ \\
\hline \multirow{2}{*}{ Global cognition } & MMSE (SD) & $23.91(4.70)$ & $22.00(4.90)$ \\
\hline & CDR (SD) & $0.69(0.52)$ & $0.72(0.45)$ \\
\hline \multirow{5}{*}{ Laboratory test } & Neutrophil, \% (SD) & $56.42(9.09)$ & $56.64(8.91)$ \\
\hline & Monocyte, \% (SD) & $8.15(1.64)$ & $11.05(19.01)$ \\
\hline & $\mathrm{ESR}(\mathrm{SD}), \mathrm{mm} / \mathrm{h}$ * & $15.29(11.65)$ & $10.91(7.00)$ \\
\hline & CRP (SD) & $0.23(0.46)$ & $0.21(0.48)$ \\
\hline & $\mathrm{LDL}(\mathrm{SD}), \mathrm{mg} / \mathrm{dL}$ * & $104.68(39.24)$ & $127.03(38.21)$ \\
\hline
\end{tabular}

Student's $t$-test was used for the analyses of the age, educational level, disease duration, MMSE, CDR, and neutrophil, monocyte, ESR, CRP, and LDL levels. The $\chi^{2}$ test was used for the analyses of sex distribution, ApoE $\varepsilon 4, \mathrm{DM}, \mathrm{HTN}$, and hyperlipidemia. Abbreviations: DM, diabetes mellitus; HTN, hypertension; MMSE, Mini-Mental Status Examination; CDR, Clinical Dementia Rating; ESR, erythrocyte sedimentation rate; CRP, C-reactive proteins; LDL, low-density lipoprotein; SD, standard deviation. * Significant at $p<0.05 .{ }^{* *}$ Significant at $p<0.001$.

(A)
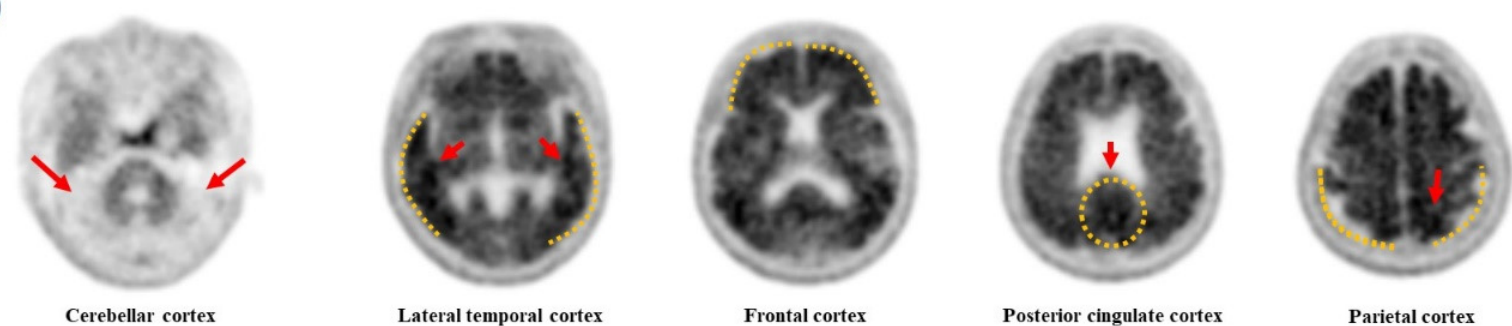

(B)
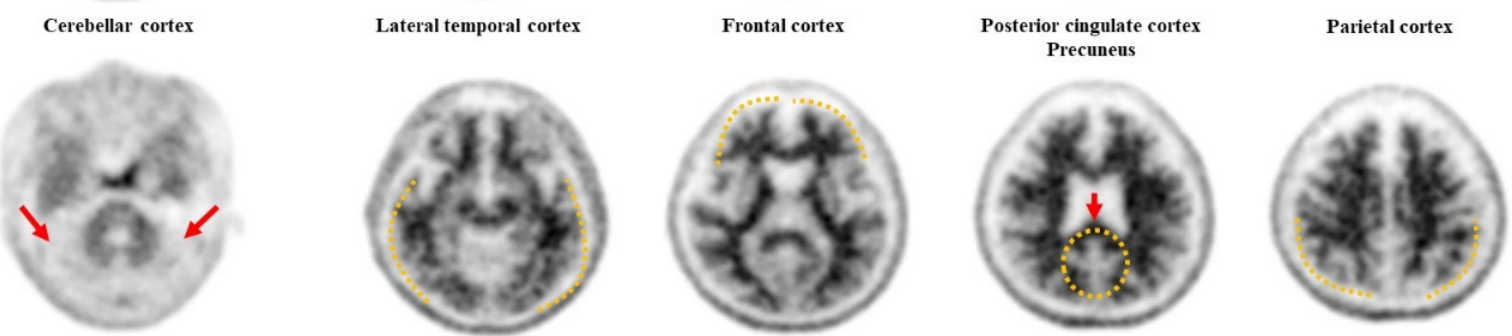

Figure 6. Gray-scale images of fluorine-18 $\left[{ }^{18} \mathrm{~F}\right]$-florbetaben amyloid PET. (A) Typical amyloid PET image of BAPL3. An increased florbetaben tracer uptake was observed not only in the bilateral frontal and parietal cortex, but also in the anterior striatum. The differentiation of the cortical gray matter and subcortical white matter disappeared. (B) Typical amyloid PET image of BAPL1. The cortical-subcortical demarcation was well maintained, and no florbetaben tracer uptake was observed in the cerebral cortex. 
(A)

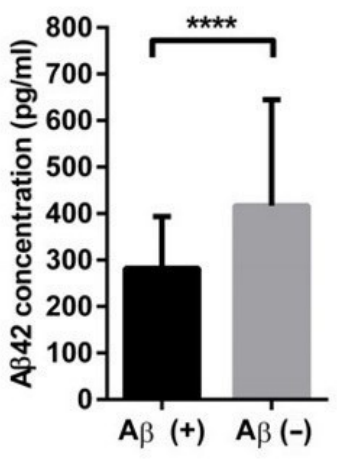

(C)

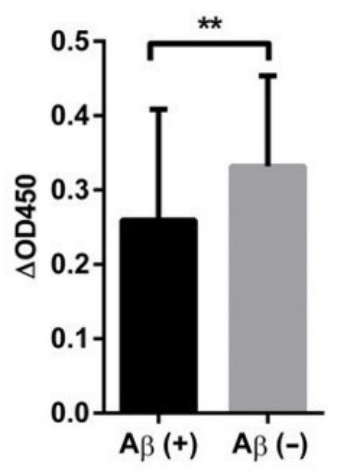

(B)

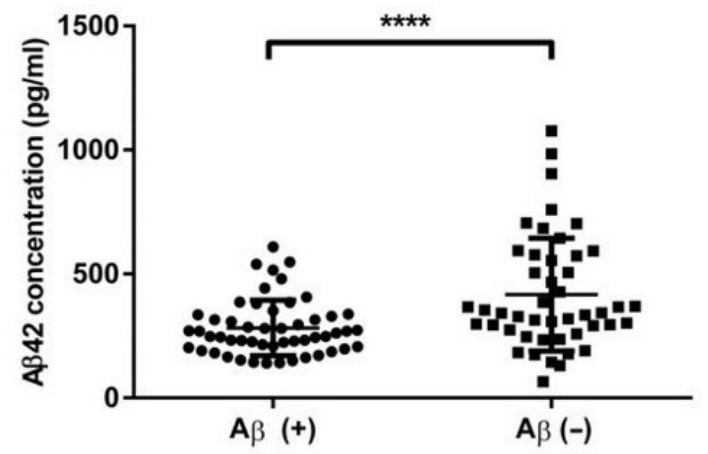

(D)

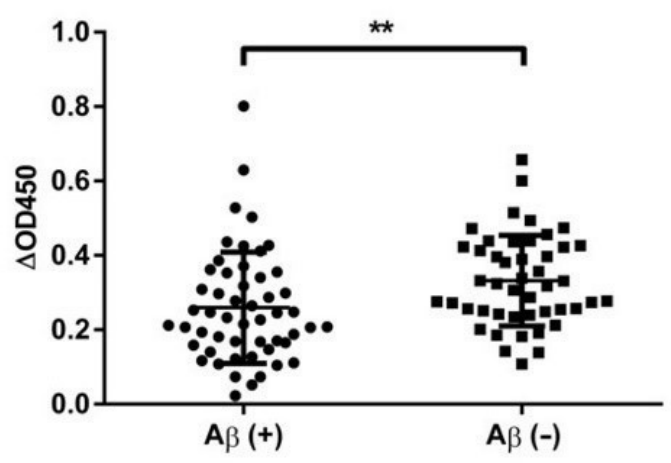

Figure 7. Comparison of the ELISA and peptide systems using the CSF samples. (A) The average of the $A \beta 42$ signals estimated using ELISA and the results of the unpaired $t$-test comparing the positive and negative categories (**** $p \leq 0.0001$ ). (B) Box plot of the A $\beta 42$ signal distributions in each group using ELISA (**** $p \leq 0.0001)$. (C) The average of the A $\beta 42$ signals estimated using the ABPPbased method and the results of the unpaired $t$-test comparing the positive and negative categories $\left.{ }^{* *} p \leq 0.01\right)$. (D) Box plot of the A $\beta 42$ signal distributions in each group using the ABPP-based method $(* * p \leq 0.01)$.

\section{Discussion}

In this study, we developed an $\mathrm{A} \beta 42$ detection system using a peptide as a signaling probe. Although sandwich ELISA is an easily accessible method for measuring target concentrations, it is not very precise when detecting $A \beta s$. To overcome the limitations of the general sandwich ELISA, which could not be used to analyze the lower molecular weight amyloid aggregates, we attempted to develop a peptide probe for $A \beta 42$. Unlike sandwich ELISA, our developed method uses antibodies only once to capture the target.

The peptide was screened using phage display as a signaling probe. For biopanning, $\mathrm{A} \beta 42$ was fixed onto the plate and captured by the antibody. Then, phage binding, washing, elution, and amplification for the next screening rounds proceeded under harsh conditions. Due to the use of an antibody as a capture probe, our system shows specificity toward A $\beta 42$. For the fixation of antibodies on the plate surface, we used protein G-coated plates, which increased the efficiency of antibody fixation by helping the antibodies face the same direction [49]. Fluorescence was measured to optimize the antibody-binding conditions. The fluorescence intensity decreased with increasing concentrations of the anti-A $\beta 42$ antibodies. Decreased fluorescence intensity indicates that the non-labeled anti-A $\beta 42$ antibody was packed on the surface of the plate and saturated in the same direction.

Among the screened peptides, we selected one sequence based on its solubility and synthesized it. Another sequence had too few hydrophilic residues, which affected its 
solubility. Because hydrophobic sequences require organic solvents, we synthesized the most hydrophilic sequence [50]. The synthesized peptide was labeled with biotin for signaling, and the absorbance increased as the concentration of the peptide increased. The binding affinity of the biotin-labeled peptide was estimated to be in the micromolar range. Due to its strong affinity, ABPP was used as a signaling probe for the next procedure.

To quantify $\mathrm{A} \beta 42$, we performed regression analysis. The high $R^{2}$ value indicates that our standard curve showed a good linear relationship between the OD450 value and A $\beta 42$ concentration [51]. For accuracy, a diagnostic method was needed that emits signals only in response to $A \beta 42$. Four prion proteins were used to validate specific binding during the analysis. Among them, A $\beta 42$ showed much higher absorbance values than the others, demonstrating that our analysis method can distinguish $A \beta 42$ from other proteins in solution. To verify the specificity of our analysis method, we used two types of antibodies that can target either $A \beta 42$ or $A \beta 40$. Much lower absorbance values were obtained when using the anti-A $\beta 40$ antibody than when using the anti-A $\beta 42$ antibody, which indicates that the specificity derives from the use of a suitable antibody. Furthermore, because of the consensus sequences between A $\beta$ proteins, the specificity of ABPP was estimated by adding $A \beta$ proteins to anti- $A \beta$ antibody-coated plates. The absorbance signals observed when $A \beta 40$ was added to anti-A $\beta 40$ antibody, which recognizes the C-terminus of $A \beta 40$ (from L34 to V40), were completely different from the absorbance signals observed when $A \beta 42$ was added to anti- $A \beta 42$, despite their consensus sequences. Interestingly, however, the absorbance resulting from adding $A \beta 40$ to antibody-coated plates that recognized different epitopes (from D1 to H14) showed almost the same signals as the established $A \beta 42$ detection. It seems that the recognition site of ABPP in $A \beta$ was affected and overlapped with the epitope of the anti-A $\beta 40$ antibody (from L34 to V40). To predict noncovalent interactions between peptide and $A \beta 42$, molecular docking analysis was performed, and the results also supported the comparison results using antibodies. The seven amino acid residues of $A \beta 42$ were found to interact with five residues of ABPP forming hydrogen bonds. These amino acid residues of $A \beta 42$ that are involved in peptide binding overlapped partially with the epitope of the anti-A $\beta 40$ antibody (from L34 to V40), and most of them were next to the epitope that can be affected by steric hindrance [52]. To verify the ability to detect $A \beta 42$ not only from $A \beta 42$ dilutions, but also from the protein mixture, $A \beta 42$ was spiked and recovered. The high average percentage recovery means that our diagnostic methods can segregate the target, even if it is in a protein mixture.

Fluorine-18-florbetaben amyloid PET is a useful clinical tool for the visualization of amyloid plaques in patients with AD [53]. The PET image showed that uptake of the PET tracer diminished the demarcation of the gray and white matter. This means that ${ }^{18} \mathrm{~F}-$ florbetaben detected cortical amyloid aggregates in patients. All participants were divided into two groups based on their amyloid PET results: amyloid-positive and -negative. Our dataset included 24 subjects aged $<65$ years who had an early onset of symptoms. Therefore, the apparent difference in age and baseline cognitive function between the two groups can be attributed to these early onset patients. The higher number of $A p o E$ $\varepsilon 4$ allele carriers in the amyloid-positive group was also consistent with that in previous studies [54]. Furthermore, PET results—amyloid-positive or -negative—can be used as a criterion for the precision of ELISA and the diagnostic methods we developed. Interestingly, although there was also an overlapping area, the absorbance estimated using ABPP-based diagnostic methods showed a very significant difference between the amyloid-positive and -negative groups. In the amyloid-positive group, the absorbance values were estimated to be lower than those in the amyloid-negative group, similar to the ELISA results. The mean concentration of $A \beta 42$ in the CSF of $A D$ and non-AD patients was $410 \pm 200 \mathrm{pg} / \mathrm{mL}$ and $657 \pm 208 \mathrm{pg} / \mathrm{mL}$, respectively [55]. As described above, the concentration of $A \beta 42$ in the CSF decreases due to the deposition of $A \beta 42$ in the brain, which is consistent with our results [56]. This means that our screened $\mathrm{ABPP}$ and the developed method can distinguish patients who have $A \beta 42$ depositions in the brain and can be helpful for $A \beta 42$ quantification, even in the monomeric state. Aprile et al. precisely showed that their newly developed 
single-domain antibody specifically recognized the oligomeric form of $A \beta 42$ rather than the other forms such as monomeric and fibrillar [24]. However, the recognition of the monomeric form of $\mathrm{A} \beta 42$ by the antibody was not mentioned therein. As shown in our supplementary results (Figure S1), our peptide can bind to monomeric as well as some oligomeric forms of $A \beta 42$, thus, the peptide could be used to detect these forms of $A \beta 42$. It would have been ideal if we tested the binding of our peptide to different conformers rather than doing TEM, which is subjective to surface-mass transport issues during sample deposition and differential binding of A $\beta 42$ conformers to the TEM grid. TEM alone might not add much evidence as to which species our peptide binds. In addition, our results would be strengthened if we could quantify the binding of our peptide to at least monomers and fibrils (and ideally also stabilized oligomers). Therefore, we think further studies might need to be done to deal with these issues in the future. Nonetheless, our research will be helpful for clinical research on AD because of the difficulties in analyzing the relationship between the monomer state of $\mathrm{A} \beta 42$ and the progression of $\mathrm{AD}$. Moreover, they can also specifically detect $A \beta 40$ when an appropriate antibody is used for coating.

\section{Conclusions}

In this study, we identified the peptide sequence that bound most strongly to the monomeric state of $A \beta 42$, and our screened peptide showed specific binding to only $A \beta 42$ using the developed system. The binding sites were also estimated and matched using molecular docking analyses. Finally, patients with amyloid depositions in the brain were distinguished using our peptide-based diagnostic method. Our diagnostic method still has problems, such as its sensitivity and specificity; however, our peptide and the diagnostic method are helpful for several clinical research areas in the AD field because of their potential to detect the monomeric state of $A \beta 42$. Using a peptide has several benefitssuch as its small size, non-immunogenicity, stability, and ease of modification-not only in terms of research but also in commercial applications. These advantages of using a peptide probe as an alternative to antibodies appear to be relevant to AD research.

Supplementary Materials: The following are available online at https:/ /www.mdpi.com/article/10.3390/ biom11121818/s1, Figure S1: The TEM image of each time point during the amyloid aggregation process and determination of its signal via a developed protocol.

Author Contributions: Conceptualization, S.-H.K. (Sang-Heon Kim) and E.-H.L.; methodology, S.-H.K. (Sang-Heon Kim); software, H.-J.K.; validation, S.-H.K. (Sang-Heon Kim) and A.-R.K.; formal analysis, E.-H.L.; investigation, Y.-E.K.; writing —original draft preparation, S.-H.K. (Sang-Heon Kim), E.-H.L. and H.-J.K.; writing-review and editing, S.-H.K. (Sang-Heon Kim), E.-H.L. and H.-J.K.; visualization, H.-J.K.; supervision, M.-Y.Y., J.-H.L. and S.-H.K. (Seong-Ho Koh); project administration, S.-H.K. (Seong-Ho Koh); funding acquisition, S.-H.K. (Seong-Ho Koh) and J.-H.L. All authors have read and agreed to the published version of the manuscript.

Funding: This research was supported by grants from the Korea Health Technology R\&D Project through the Korea Health Industry Development Institute, funded by the Ministry of Health \& Welfare, Republic of Korea (HI18C1254, HI20C0253, HU21C0007, and HU21C0113).

Institutional Review Board Statement: Informed consent This study was conducted according to the guidelines of the Declaration of Helsinki, and approved by the Institutional Review Board of Asan Medical Center (\#2018-0614, May 28 2018).

Informed Consent Statement: Informed consent was obtained from all subjects involved in the study. Written informed consent was obtained from the patients for publication of this paper.

Data Availability Statement: Due to privacy and ethical concerns, the data that support the findings of this study are available on request from the first authors (S.H. Kim, E.H. Lee, and H.J. Kim).

Conflicts of Interest: The authors declare no conflict of interest. 


\section{References}

1. Ma, S.; Chen, G.; Xu, J.; Liu, Y.; Li, G.; Chen, T.; Li, Y.; James, T.D. Current strategies for the development of fluorescence-based molecular probes for visualizing the enzymes and proteins associated with Alzheimer's disease. Coord. Chem. Rev. 2021, 427, 213553. [CrossRef]

2. Kim, Y.J.; Park, H.; Park, J.H.; Park, K.W.; Lee, K.; Kim, S.; Chae, K.; Park, M.H.; Koh, S.H.; Na, H.R. Effects of multicomponent exercise on cognitive function in elderly Korean individuals. J. Clin. Neurol. 2020, 16, 612-623. [CrossRef] [PubMed]

3. Xu, J.Q.; Murphy, S.L.; Kochanek, K.D.; Arias, E. Mortality in the United States, 2018; NCHS Data Brief No. 355; National Center for Health Statistics: Hyattsville, MD, USA, 2020.

4. Jang, J.W.; Park, J.H.; Kim, S.; Lee, S.H.; Lee, S.H.; Kim, Y.J. Prevalence and incidence of dementia in South Korea: A nationwide analysis of the National Health Insurance Service Senior Cohort. J. Clin. Neurol. 2021, 17, 249-256. [CrossRef] [PubMed]

5. Park, H.K.; Jeong, J.H.; Moon, S.Y.; Park, Y.K.; Hong, C.H.; Na, H.R.; Song, H.S.; Lee, S.M.; Choi, M.; Park, K.W.; et al. South Korean study to prevent cognitive impairment and protect brain health through lifestyle intervention in at-risk elderly people: Protocol of a multicenter, randomized controlled feasibility trial. J. Clin. Neurol. 2020, 16, 292-303. [CrossRef]

6. Alexander, G.C.; Emerson, S.; Kesselheim, A.S. Evaluation of aducanumab for Alzheimer disease: Scientific evidence and regulatory review involving efficacy, safety, and futility. JAMA 2021, 325, 1717-1718. [CrossRef]

7. Sappagh, S.E.; Saleh, H.; Sahal, R.; Abuhmed, T.; RiazulIslam, S.M.; Ali, F.; Amer, E. Alzheimer's disease progression detection model based on an early fusion of cost-effective multimodal data. Future Gener. Comput. Syst. 2021, 115, 680-699. [CrossRef]

8. Rasmussen, J.; Langerman, H. Alzheimer's disease-Why we need early diagnosis. Degener. Neurol. Neuromuscul. Dis. 2019, 9, 123-130. [CrossRef] [PubMed]

9. Zetterberg, H.; Bendlin, B.B. Biomarkers for Alzheimer's disease-Preparing for a new era of disease-modifying therapies. Mol. Psychiatry 2021, 26, 296-308. [CrossRef] [PubMed]

10. Selkoe, D.J.; Hardy, J. The amyloid hypothesis of Alzheimer's disease at 25 years. EMBO Mol. Med. 2016, 8, 595-608. [CrossRef] [PubMed]

11. Cazarin, C.A.; Dalmagro, A.P.; Gonçalves, A.E.; Boeing, T.; Silva, L.M.D.; Corrêa, E.; Klein-Júnior, L.C.; Pinto, B.C.; Lorenzett, T.S.; Sobrinho, T.U.D.C.; et al. Usnic acid enantiomers restore cognitive deficits and neurochemical alterations induced by A $\beta 1-42$ in mice. Behav. Brain Res. 2021, 397, 112945. [CrossRef] [PubMed]

12. Qu, Z.S.; Li, L.; Sun, X.J.; Zhao, Y.W.; Zhang, J.; Geng, Z.; Fu, J.L.; Ren, Q.G. Glycogen synthase kinase-3 regulates production of amyloid- $\beta$ peptides and tau phosphorylation in diabetic rat brain. Sci. World J. 2014, 2014, 878123. [CrossRef]

13. Potter, R.; Patterson, B.W.; Elbert, D.L.; Ovod, V.; Kasten, T.; Sigurdson, W.; Mawuenyega, K.; Blazey, T.; Goate, A.; Chott, R.; et al. Increased in vivo amyloid- $\beta 42$ production, exchange, and loss in presenilin mutation carriers. Sci. Transl. Med. 2013, 5, 189ra77. [CrossRef]

14. LaFerla, F.M.; Green, K.N.; Oddo, S. Intracellular amyloid-beta in Alzheimer's disease. Nat. Rev. Neurosci. 2007, 8, 499-509. [CrossRef]

15. Varvel, N.H.; Bhaskar, K.; Patil, A.R.; Pimplikar, S.W.; Herrup, K.; Lamb, B.T. Abeta oligomers induce neuronal cell cycle events in Alzheimer's disease. J. Neurosci. 2008, 28, 10786-10793. [CrossRef] [PubMed]

16. Fagan, A.M.; Mintun, M.A.; Mach, R.H.; Lee, S.Y.; Dence, C.S.; Shah, A.R.; LaRossa, G.N.; Spinner, M.L.; Klunk, W.E.; Mathis, C.A.; et al. Inverse relation between in vivo amyloid imaging load and cerebrospinal fluid A $\beta 42$ in humans. Ann. Neurol. 2006, 59, 512-519. [CrossRef] [PubMed]

17. Grimmer, T.; Riemenschneider, M.; Förstl, H.; Henriksen, G.; Klunk, W.E.; Mathis, C.A.; Shiga, T.; Wester, H.J.; Kurz, A.; Drzezga, A. Beta amyloid in Alzheimer's disease: Increased deposition in brain is reflected in reduced concentration in cerebrospinal fluid. Biol. Psychiatry 2009, 65, 927-934. [CrossRef] [PubMed]

18. Strozyk, D.; Blennow, K.; White, L.R.; Launer, L.J. CSF A $\beta 42$ levels correlate with amyloid-neuropathology in a population-based autopsy study. Neurology 2003, 60, 652-656. [CrossRef]

19. Tapiola, T.; Alafuzoff, I.; Herukka, S.K.; Parkkinen, L.; Hartikainen, P.; Soininen, H.; Pirttilä, T. Cerebrospinal fluid $\beta$-amyloid 42 and tau proteins as biomarkers of Alzheimer-type pathologic changes in the brain. Arch. Neurol. 2009, 66, 382-389. [CrossRef]

20. Tolboom, N.; Flier, W.M.V.D.; Yaqub, M.; Boellaard, R.; Verwey, N.A.; Blankenstein, M.A.; Windhorst, A.D.; Scheltens, P.; Lammertsma, A.A.; Berckel, B.N.M.V. Relationship of cerebrospinal fluid markers to 11C-PiB and 18F-FDDNP binding. J. Nucl. Med. 2009, 50, 1464-1470. [CrossRef] [PubMed]

21. Kim, K.Y.; Kim, M.J.; Kim, D.W.; Kim, S.Y.; Park, S.; Park, C.B. Clinically accurate diagnosis of Alzheimer's disease via multiplexed sensing of core biomarkers in human plasma. Nat. Commun. 2020, 11, 119. [CrossRef] [PubMed]

22. Klafki, H.W.; Rieper, P.; Matzen, A.; Zampar, S.; Wirths, O.; Vogelgsang, J.; Osterloh, D.; Rohdenburg, L.; Oberstein, T.J.; Jahn, O.; et al. Development and technical validation of an immunoassay for the detection of app $669-711\left(\mathrm{~A} \beta_{-3-40}\right)$ in biological samples. Int. J. Mol. Sci. 2020, 21, 6564. [CrossRef] [PubMed]

23. Sung, W.H.; Hung, J.T.; Lu, Y.J.; Cheng, C.M. Paper-based detection device for Alzheimer's disease-Detecting $\beta$-amyloid peptides (1-42) in human plasma. Diagnostics 2020, 10, 272. [CrossRef]

24. Aprile, F.A.; Sormanni, P.; Podpolny, M.; Chhangur, S.; Needham, L.M.; Ruggeri, F.S.; Perni, M.; Limbocker, R.; Heller, G.T.; Sneideris, T.; et al. Rational design of a conformation-specific antibody for the quantification of A $\beta$ oligomers. Proc. Natl. Acad. Sci. USA 2020, 117, 13509-13518. [CrossRef]

25. Yang, G.; Velgos, S.N.; Boddapati, S.P.; Sierks, M.R. Probing antibody-antigen interactions. Microbiol. Spectr. 2014, 2, 1-13. [CrossRef]

26. Sakamoto, S.; Putalun, W.; Vimolmangkang, S.; Phoolcharoen, W.; Shoyama, Y.; Tanaka, H.; Morimoto, S. Enzyme-linked immunosorbent assay for the quantitative/qualitative analysis of plant secondary metabolites. J. Nat. Med. 2018, 72, 32-42. [CrossRef] [PubMed] 
27. Wang, M.J.; Yi, S.H.; Han, J.Y.; Park, S.Y.; Jang, J.W.; Chun, I.K.; Kim, S.E.; Lee, B.S.; Kim, G.J.; Yu, J.S.; et al. Oligomeric forms of amyloid- $\beta$ protein in plasma as a potential blood-based biomarker for Alzheimer's disease. Alzheimer's Res. Ther. 2017, 9, 98. [CrossRef] [PubMed]

28. Janssen, L.; Sobott, F.; Deyn, P.P.D.; Dam, D.V. Signal loss due to oligomerization in ELISA analysis of amyloid-beta can be recovered by a novel sample pre-treatment method. MethodX 2015, 2, 112-123. [CrossRef]

29. Kim, S.H.; Lee, E.H.; Lee, S.C.; Kim, A.R.; Park, H.H.; Son, J.W.; Koh, S.H.; Yoon, M.Y. Development of peptide aptamers as alternatives for antibody in the detection of amyloid-beta 42 aggregates. Anal. Biochem. 2020, 609, 113921. [CrossRef] [PubMed]

30. Lee, J.I.; Jang, S.C.; Chung, J.; Choi, W.K.; Hong, C.; Ahn, G.R.; Kim, S.H.; Lee, B.Y.; Chung, W.J. Colorimetric allergenic fungal spore detection using peptide-modified gold nanoparticles. Sens. Actuators B Chem. 2021, 327, 128894. [CrossRef]

31. Wang, X.Y.; Yang, J.Y.; Wang, Y.T.; Zhang, H.C.; Chen, M.L.; Yang, T.; Wang, J.H. M13 phage-based nanoprobe for SERS detection and inactivation of Staphylococcus aureus. Talanta 2021, 221, 121668. [CrossRef]

32. Feng, S.; Shi, R.; Xu, P.; Bhamore, J.R.; Bal, J.; Baek, S.H.; Park, C.Y.; Park, J.P.; Park, T.J. Colorimetric detection of creatinine using its specific binding peptides and gold nanoparticles. New J. Chem. 2020, 44, 15828-15835. [CrossRef]

33. Colombo, M.; Mizzotti, C.; Masiero, S.; Kater, M.M.; Pesaresi, P. Peptide aptamers: The versatile role of specific protein function inhibitors in plant biotechnology. J. Integr. Plant Biol. 2015, 57, 892-901. [CrossRef]

34. Sachdeva, S.; Joo, H.; Tsai, J.; Jasti, B.; Li, X. A rational approach for creating peptides mimicking antibody binding. Sci. Rep. 2019, 9, 997. [CrossRef] [PubMed]

35. Reverdatto, S.; Burz, D.S.; Shekhtman, A. Peptide aptamers: Development and applications. Curr. Top. Med. Chem. 2015, 15, 1082-1101. [CrossRef]

36. De, S.; Whiten, D.R.; Ruggeri, F.S.; Hughes, C.; Rodrigues, M.; Sideris, D.I.; Taylor, C.G.; Aprile, F.A.; Muyldermans, S.; Knowles, T.P.J.; et al. Soluble aggregates present in cerebrospinal fluid change in size and mechanism of toxicity during Alzheimer's disease progression. Acta Neuropathol. Commun. 2019, 7, 120. [CrossRef] [PubMed]

37. Glucksman, M.J.; Bhattacharjee, S.; Makowski, L. Three-dimensional structure of a cloning vector. X-ray diffraction studies of filamentous bacteriophage M13 at 7 A resolution. J. Mol. Biol. 1992, 226, 455-470. [CrossRef]

38. Lee, S.C.; Kim, S.H.; Hoffmeister, R.A.; Yoon, M.Y.; Kim, S.K. Novel peptide-based inhibitors for microtubule polymerization in Phytophthora capsica. Int. J. Mol. Sci. 2019, 20, 2641. [CrossRef]

39. Pande, J.; Szewczyk, M.M.; Grover, A.K. Phage display: Concept, innovations, applications and future. Biotechnol. Adv. 2010, 28, 849-858. [CrossRef] [PubMed]

40. Stine, W.B.; Jungbauer, L.; Yu, C.; Ladu, M.J. Preparing synthetic A $\beta$ in different aggregation states. Methods Mol. Biol. 2011, 670, 13-32. [CrossRef] [PubMed]

41. Fukuta, T.; Asai, T.; Kiyokawa, Y.; Nakada, T.; Bessyo-Hirashima, K.; Fukaya, N.; Hyodo, K.; Takase, K.; Kikuchi, H.; Oku, N. Targeted delivery of anticancer drugs to tumor vessels by use of liposomes modified with a peptide identified by phage biopanning with human endothelial progenitor cells. Int. J. Pharm. 2017, 524, 364-372. [CrossRef]

42. Cho, J.H.; Ha, N.R.; Koh, S.H.; Yoon, M.Y. Design of a PKC $\delta$-specific small peptide as a theragnostic agent for glioblastoma. Anal. Biochem. 2016, 496, 63-70. [CrossRef]

43. Trott, O.; Olson, A.J. AutoDock Vina: Improving the speed and accuracy of docking with a new scoring function, efficient optimization, and multi-threading. J. Comput. Chem. 2010, 31, 455-461. [CrossRef] [PubMed]

44. Tomaselli, S.; Esposito, V.; Vangone, P.; Nuland, N.A.V.; Bonvin, A.M.; Guerrini, R.; Tancredi, T.; Temussi, P.A.; Picone, D. The alpha-to-beta conformational transition of Alzheimer's Abeta-(1-42) peptide in aqueous media is reversible: A step by step conformational analysis suggests the location of beta conformation seeding. Chembiochem 2006, 7, 257-267. [CrossRef]

45. Sabri, O.; Seibyl, J.; Rowe, C.; Barthelt, H. Beta-amyloid imaging with florbetaben. Clin. Transl. Imaging 2015, 3, 13-26. [CrossRef] [PubMed]

46. Jeong, K.E.; Jeong, Y.J.; Park, K.W.; Kang, D.Y. Cerebral amyloid quantification in cognitively normal Korean adults using F-18 Florbetaben PET. Nucl. Med. Mol. Imaging 2019, 53, 334-339. [CrossRef]

47. Bullich, S.; Seibyl, J.; Catafau, A.M.; Jovalekic, A.; Koglin, N.; Barthel, H.; Sabri, O.; Santi, S.D. Optimized classification of 18F-Florbetaben PET scans as positive and negative using an SUVR quantitative approach and comparison to visual assessment. Neuroimage Clin. 2017, 15, 325-332. [CrossRef]

48. Aisen, P.S.; Cummings, J.; Jack, C.R. On the path to 2025: Understanding the Alzheimer's disease continuum. Alzheimer's Res. Ther. 2017, 9, 60. [CrossRef]

49. Welch, N.G. Orientation and characterization of immobilized antibodies for improved immunoassays (Review). Biointerphases 2017, 12, 02D301. [CrossRef]

50. Gil, J.P.; Cruz, A.; Casals, C. Solubility of hydrophobic surfactant proteins in organic solvent/water mixtures. Structural studies on SP-B and SP-C in aqueous organic solvents and lipids. Biochim. Biophys. Acta 1993, 1168, 261-270.

51. Nie, X.; Chen, Z.; Tian, Y.; Chen, S.; Qu, L.; Fan, M. Rapid detection of trace formaldehyde in food based on surface-enhanced Raman scattering coupled with assembled purge trap. Food Chem. 2020, 340, 127930. [CrossRef] [PubMed]

52. Klein, J.S.; Gnanapragasam, P.N.P.; Galimidi, R.P.; Foglesong, C.P.; West, A.P., Jr.; Bjorkman, P.J. Examination of the contributions of size and avidity to the neutralization mechanisms of the anti-HIV antibodies b12 and 4E10. Proc. Natl. Acad. Sci. USA 2009, 106, 7385-7390. [CrossRef] [PubMed]

53. Villemagne, V.L.; Ong, K.; Mulligan, R.S.; Holl, G.; Pejoska, S.; Jones, G.; O’Keefe, G.; Ackerman, U.; Danguy, H.T.; Chan, J.G.; et al. Amyloid imaging with ${ }^{18}$ F-florbetaben in Alzheimer disease and other dementias. J. Nucl. Med. 2011, 52, 1210-1217. [CrossRef] [PubMed] 
54. Kanekiyo, T.; Xu, H.; Bu, G. ApoE and A $\beta$ in Alzheimer's disease: Accidental encounters or partners? Neuron 2014, 81, 740-754. [CrossRef] [PubMed]

55. Baldeiras, I.; Santana, I.; Leitão, M.J.; Ribeiro, M.H.; Pascoal, R.; Duro, D.; Lemos, R.; Santiago, B.; Almeida, M.R.; Oliveira, C.R. Cerebrospinal fluid A $\beta 40$ is similarly reduced in patients with frontotemporal lobar degeneration and Alzheimer's Disease. J. Neurol. Sci. 2015, 358, 308-316. [CrossRef] [PubMed]

56. Li, X.; Li, T.Q.; Andreasen, N.; Wiberg, M.K.; Westman, E.; Wahlund, L.O. Ratio of A $\beta 42 /$ P-tau181p in CSF is associated with aberrant default mode network in AD. Sci. Rep. 2013, 3, 1339. [CrossRef] [PubMed] 